\title{
Implikasi Kesepakatan ASEAN Banking Integration Framework (ABIF) terhadap Pembaruan Hukum Perbankan Indonesia
}

\author{
Tri Handayani, Lastuti Abubakar \\ Universitas Padjadjaran \\ h212tri@gmail.com
}

\begin{abstract}
ASEAN Banking Integration Framework Agreements (ABIF) will be implemented in 2020 and will change the legal based of the Indonesian Banking Law No: 7 of 1992 as amended by Law No: 10 of 1998 Regarding Banking, no longer can be used as a legal protection to regulate changes in banking activities Indonesia, especially to take advantage of the opportunity to compete with the banks of the ASEAN countries which will operate in Indonesia. Therefore, the necessary reform banking laws can be a solid legal foundation for the Indonesian banking activities to prepare for anticipating developments in global banking. The government has issued Law No: 92016 Regarding Prevention and Crisis Management, Financial System, Which reflects the importance of macro prudential policy to avoid, and reduce systemic risk and increase the resilience of the financial system, which is largely the contribution of banking. In addition, the government has initiated the draft Banking Act in order to meet regulatory standards demanded and required by global banking development.
\end{abstract}

Keywords: global banking development, banking law reform.

\begin{abstract}
Abstrak
Kesepakatan ASEAN Banking Integration Framework (ABIF) yang akan dilaksanakan pada Tahun 2020 akan mengubah tatanan hukum Perbankan Indonesia. UU No: 7 Tahun 1992 sebagaimana telah diubah dengan UU No: 10 Tahun 1998 Tentang Perbankan dianggap tidak dapat lagi digunakan sebagai payung hukum untuk mengatur perubahan aktivitas perbankan Indonesia, khususnya untuk memanfaatkan peluang bersaing dengan Bank-bank dari negara ASEAN yang akan beroperasi di Indonesia. Oleh karena itu, diperlukan pembaruan hukum perbankan yang dapat menjadi landasan hukum yang kokoh bagi aktivitas perbankan Indonesia untuk mempersiapkan diri guna mengantisipasi perkembangan perbankan global. Pemerintah telah menerbitkan UU No : 9 Tahun 2016 Tentang Pencegahan dan Penanganan Krisis Sistem Keuangan (UU PPKSK), yang merefleksikan pentingnya kebijakan makroprudensial untuk mecegah dan mengurangi risiko sistemik dan meningkatkan ketahanan sistem keuangan, yang sebagian besar merupakan kontribusi perbankan.Selain itu, pemerintah telah menggagas Rancangan UU Perbankan guna memenuhi standar regulasi yang dituntut dan diperlukan oleh perkembangan perbankan global.
\end{abstract}

Kata kunci: perkembangan perbankan global, pembaruan hukum perbankan.

\section{Pendahuluan}

Gejolak perekonomian dunia, khususnya pasca krisis global, berdampak kepada kondisi pasar keuangan domestik, selain disebabkan oleh perlambatan ekonomi domestik serta pasar uang dan pasar modal yang masih tersegmentasi dan dangkal. Dari 
sisi risiko, pasar keuangan domestik masih relatif terjaga ditengah tekanan yang cenderung meningkat terutama di pasar uang antar bank, valas, saham dan surat berharga negara (SBN). Hal tersebut tidak terlepas dari upaya mitigasi risiko dan langkah-langkah pendalaman pasar keuangan yang telah dilakukan oleh Bank Indonesia, otoritas keuangan lainnya dan industri.

Di sisi lain, kebutuhan akan jasa perbankan berkembang pesat sebagai dampak perkembangan perekonomian baik .internasional maupun nasional, sehingga diperlukan legal basis yang kokoh bagi aktivitas perbankan Indonesia, dan perannya sebagai penggerak perekonomian Indonesia untuk

mencapai tujuan pembangunan sebagaimana di jelaskan dalam Buku II Rencana Pembangunan Jangka Menengah Nasional (RPJMN) Tahun 2015-2019. Bab 3 RPJMN Tentang Pembangunan Ekonomi menyatakan bahwa pembangunan sektor keuangan difokuskan kepada ketahanan dan daya saing sektor keuangan. Peningkatan ketahanan dan daya saing sektor keuangan bertujuan untuk meningkatkan kesejahteraan rakyat melalui pencapaian stabilitas sektor keuangan yang berkontribusi pada stabilitas ekonomi, pertumbuhan ekonomi berkelanjutan, serta pembangunan ekonomi inklusif dan berkeadilan.

Berbicara mengenai kesejahteraan rakyat, mengacu kepada pendapat Sunaryati Hartono, yang dimaksud dengan kesejahteraan rakyat disini adalah adanya keseimbangan penyelenggaraan kebutuhan masyarakat sebagai satu keseluruhan dan kebutuhan perseorangan sebagai bagian daripada keseluruhan masyarakat itu. Dengan kata lain kesejahteraan masyarakat Indonesia, baik dalam arti masyarakat sebagai satu kesatuan, maupun untuk mencapai kesejahteraan bagi setiap warga negara Indonesia (Sunaryati hartono; 1988:17) sebagaimana didalilkan dalam Pasal 27 ayat (2) UUD 1945 yang menyatakan bahwa:

“Tiap-tiap warga negara berhak atas pekerjaan dan penghidupan yang layak bagi kemanusiaan"

Berdasarkan uraian diatas jelaslah bahwa kesejahteraan rakyat yang dimaksud adalah kesejahteraan yang mencapai suatu keadilan sosial sesuai dengan kehendak falsafah bangsa Indonesia yaitu Pancasila.

Memperhatikan peranan lembaga perbankan yang sedemikian strategis dalam mencapai tujuan pembangunan nasional maka terhadap lembaga perbankan perlu senantiasa dilakukan pembinaan dan pengawasan yang 
efektif. Perkembangan perbankan Indonesia diharapkan dapat ditingkatkan secara berkelanjutan dan bermanfaat bagi pelaksanaan pembangunan nasional. Perbankan Indonesia bertujuan mewujudkan sistem perbankan yang efisien, sehat dan stabil, untuk mendorong pertumbuhan ekonomi yang berkelanjutan dan lebih merata melalui pembiayaan yang mudah, aman, dan terjangkau dalam rangka meningkatkan kesejahteraan dan kemakmuran seluruh rakyat. Dalam melakukan kegiatan usahanya, Bank wajib menggunakan prinsip kehati-hatian dan tata kelola Bank yang baik.

Perkembangan perekonomian Internasional yang bergerak secara cepat memberikan dampak kepada perekonomian nasional terutama kepada perbankan nasional dalam menjalankan fungsinya sehingga pemerintah melihat perlunya upaya pembaruan dasar hukum perbankan agar perbankan nasional dapat memperluas ruang geraknya seperti memperluas jangkauan pelayanan, memperkuat asset permodalan dan lain sebagainya. Hal ini sejalan dengan dikeluarkannya UU No. 9 Tahun 2016 Tentang Pencegahan dan Penanganan Krisis Sistem Keuangan (UU PPKSK). UU PPKSK mengatur mengenai mekasnisme upaya penyelamatan Bank sistemik. Bank sistemik adalah Bank yang karena ukuran aset, modal dan dan kewajiban; luas jaringan atau kompleksitas transaksi atas jasa perbankan serta keterkaitan dengan sektor keuangan lain dapat mengakibatkan gagalnya sebagian atau keseluruhan bank lain atau sektor jasa keuangan, baik secara operasional maupun finansial, jika bank tersebut mengalami gangguan atau gagal (Pasal 1 UU PPSKSK). Berdasarkan UU PPKSK diatur mengenai proses penyelamatan Bank dengan menghapuskan mekanisme Bail Out dan mengutamakan proses Bail In.

Setiap institusi perbankan jika menghadapi kondisi sistemik, maka hal pertama yang wajib dilakukan adalah bagaimana Bank itu sendiri dapat bertahan dan menyelamatkan diri sendiri dengan menggunakan kekuatan sendiri. Mulai dari permodalan sampai ke total asset digunakan untuk langkah pertama upaya penyelamatan bank sistemik. Setelah itu, apabila tidak tercapai maka, Bank sistemik tersebut dimintakan untuk melakukan pengalihan asset dan kewajiban bank sistemik baru setelah itu maka Bank sistemik akan difasilitasi oleh LPS dalam melakukan pemasaran atas asset dan/atau kewajiban bank sistemik kemudian diputuskan penyerahan Bank sistemik kepada LPS untuk dilakukan penanganan 
berdasarkan undang-undang PPSK dan UU Lembaga Penjamin simpanan. Upaya pengaturan dan pengawasan bank yang efektif ditujukan untuk menjaga stabilitas sistem keuangan oleh karena itu penting untuk dapat memperkuat fungsi pengaturan dan pengawasan oleh otoritas terkait.

Selain berlakunya UU PPSK, pemerintah telah menggagas adanya Rancangan Undang-undang Perbankan, mengingat UU Perbankan yang berlaku sekarang dinilai sudah tidak sesuai dengan perkembangan industri perbankan dewasa ini. Urgensi pembaruan hukum perbankan ini dikarenakan adanya beberapa indikasi yang dalam beberapa tahun terakhir ini memerlukan pendekatan yang berbeda dari 20 tahun yang lalu, sehingga tidak dapat hanya berpayung hukum kepada UU No 10 Tahun 1998 Tentang Perubahan atas UU No. 7 Tahun 1992 Tentang Perbankan (UU Perbankan). UU Perbankan sudah tidak relevan dengan perkembangan industri perbankan global, terutama adanya kesepakatan ASEAN Banking Integration Framework (ABIF) pada tahun 2020 yang memungkinkan Bank yang berasal dari negara-negara ASEAN beroperasi di Indonesia. Oleh karena itu, industri perbankan nasional memerlukan payung hukum yang kokoh agar dapat memanfaatkan peluang dan bersaing, serta berkontribusi dalam pembangunan nasional. ABIF merupakan inisiatif dibidang perbankan di bawah kerangka Masyarakat Ekonomi ASEAN (MEA). ABIF diciptakan untuk mempercepat liberalisasi perbankan ASEAN melalui sebuah kerangka kerja integrasi perbankan ASEAN. Indonesia dituntut untuk segera mempersiapkan Bank Nasional agar dapat menembus kategori Qualified ASEAN Bank, sehingga dapat bersaing dengan Bank ASEAN lainnya. Salah satu upaya yang harus segera dipersiapkan adalah pembaruan hukum perbankan yang mampu mengantisipasi perkembangan global tersebut.

Mengutip pendapat Mochtar Kusumaatmadja, pembaruan hukum lebih memungkinkan dilaksanakan pada bidang-bidang hukum yang bersifat netral, antara lain di bidang perbankan, karena penggunaan model-model asing tidak akan menimbulkan suatu kesulitan apapun. (Mochtar Kusumaatmadja, 2002:24). Oleh karena itu salah satu upaya pembaruan hukum perbankan nasional itu dilakukan melalui perbaikan dan perubahan undang-undang Perbankan dengan memperhatikan beberapa ketentuan yang berasal dari organisasi internasional maupun regional sektor jasa keuangan maupun 
perbankan yang mana Indonesia menjadi salah satu anggotanya seperti Financial Stability Board (FSB), Banking Internasional Settlement (BIS), International Organization Of Securities Commisions (IOSCO), ASEAN Banking Integration Framework (ABIF), dan lain sebagainya.

Berdasarkan uraian di atas, maka perlu di kaji mengenai bagaimanakah urgensi pembaruan hukum perbankan dalam rangka mewujudkan stabilitas keuangan nasional serta bagaimana upaya pemerintah mengantisipasi adanya perkembangan global dalam hukum perbankan dengan di sepakatinya ASEAN Banking Integration Framework ini?

Tujuan dilaksanakannya penelitian ini adalah untuk menghasilkan kajian tentang urgensi pembaruan hukum perbankan Indonesia dalam rangka memajukan perekonomian nasional dan mengkaji kesiapan regulasi perbankan Indonesia menghadapi ASEAN Banking Integration Framework (ABIF) yang akan di laksanakan pada tahun 2020.

\section{Metode Penelitian}

Penelitian ini bersifat deskriptif analitis, yaitu membuat pencandraan secara sistematis, faktual dan akurat mengenai fakta-fakta (Sumadi, 1988:19) oleh karena itu penelitian ini sifatnya mengkaji dan memaparkan berbagai permasalahan aspek hukum dan fakta serta gejala lainnya yang berkaitan dengan perkembangan global dalam bidang khususnya denga adanya kesepakatan Indonesia untuk turus serta melaksanakan ASEAN Banking Integration Framework (ABIF) tahun 2020, kemudian menganalisisnya guna memperoleh gambaran yang utuh dan menyeluruh tentang permasalahan hukum yang berkaitan dengan Metode pendekatan yang digunakan adalah metode pendekatan yuridis normatif maka pendekatan yang digunakan antara lain menggunakan bahan hukum primer yaitu perundang-undangan, bahan hukum sekunder seperti jurnal maupun hasil penelitian sebelumnya dan bahan hukum tersier (Jhonny Ibrahim, 2013:295) Metode pendekatan yuridis normatif ini dapat menggunakan cara (Mamudji, 2005 : 9-11) : penelitian menarik asas hukum dan sinkronisasi peraturan perundang-undangan.

\section{Hasil dan Pembahasan}

Pembangunan ekonomi di Indonesia bertumpu pada beberapa unsur yang satu sama lain saling mendukung. Unsur tersebut antara lain meliputi sumber daya, modal, manusia sebagai pelaku ekonomi dan regulasi yang menjadi 
landasan hukum dan meberi arah bagi pembangunan ekonomi. Dalam konteks tulisan ini, setidaknya terdapat 3 unsur yang akan saling berkaitan, yaitu pelaku usaha sebagai penggerak ekonomi, sumber-sumber pembiayaan bagi dunia usaha, dan regulasi yang mendorong bagaimana pembiayaan tersebut dapat dioptimalkan oleh pelaku usaha.

Salah satu institusi keuangan yang berperan besar dalam aktivitas ekonomi adalah perbankan, yang berfungsi sebagai intermediary, yaitu institusi yang mempertemukan pihak yang kelebihan dana (surplus of fund) dan pihak yang kekurangan dana/membutuhkan dana (lack of fund). Kehadiran perbankan dapat mengoptimalkan dana-dana yang ada agar dapat disalurkan kepada yang memerlukan, khususnya pelaku usaha untuk menggerakkan ekonomi.

Selain berfungsi sebagai alternatif pembiayaan dunia usaha, perbankan juga menjadi alternative invetasi bagi pemilik dana, dan pada akhirnya diharapkan perbankan dapat berkontribusi terhadap pembangunan ekonomi dan mampu mensejahterakan rakyat banyak. Dapat dikatakan bahwa perbankan merupakan urat nadi perekonomian Indonesia, yang akan menghidupkan dan menjalankan perekonomian di Indonesia. Fungsi perbankan di atas tentunya harus didukung oleh regulasi yang tepat guna, agar tujuan yang diamanatkan pada perbankan dapat tercapai.

Saat ini, aktivitas perbankan bertumpu pada dua Undang-undang, yakni UU NO ; 10 Tahun 1998 Tentang Perubahan UU No : 7 Tahun 1992 Tentang Perbankan dan UU No : 21 Tahun 2008 Tentang Perbankan Syariah. Dualieme hukum perbankan ini terjadi untuk memanfaatkan sebesar-besarnya dana yang dapat dihimpun oleh pihak perbankan dan dilanjutkan disalurkan dalam bentuk kredit atau pembiayaan. Eksistensi perbankan syariah dipicu oleh perubahan tatanan ekonomi dunia pasca krisis ekonomi global. Negara-negara dunia mencoba menata kembali struktur perbankan dan seluruh institusi keuangannya agar dapat menghimpun dana, khususnya dari pemilik dana yaitu Negara-negara timur tengah yang kaya akan sumber daya migas (Negara-negara petrodollar). Indonesia tentu harus cepat melihat peluang ini, dan mengubah regulasi perbankan agar dapat memaksimalkan sumber-sumber keuangan agar dapat diinvestasikan di Indonesia.

Perbankan Indonesia memiliki tujuan strategis dan tidak semata-mata berorientasi ekonomis tetapi juga berorientasi kepada stabilitas nasional 
sebagaimana tercantum dalam Pasal 4 UU Perbankan yang berbunyi:

"Perbankan Indonesia bertujuan menunjang pelaksanaan pembangunan nasional dalam rangka meningkatkan pemerataan, pertumbuhan ekonomi dan stabilitas nasional kearah peningkatan kesejahteraan rakyat banyak"

Ketentuan di atas dapat disimpulkan bahwa lembaga perbankan memegang peranan penting dan strategis dalam menggerakkan roda perekonomian nasional yang senantiasa bergerak cepat, kompetitif, dan terintegrasi dengan tantangan yang semakin kompleks serta sistem keuangan yang semakin maju, diperlukan penyesuaian kebijakan bidang ekonomi, termasuk perbankan.

Salah satu arah kebijakan pemerintah dalam mengupayakan sumber dana pembangunan adalah dengan mengoptimalkan sumbersumber pembiayaan yang ada dan mengurangi ketergantungan dana dari luar negeri. Prinsip utama dalam kebijakan ekonomi pemerintah terletak pada peningkatan kesempatan serta kesanggupan rakyat Indonesia sendiri (swadaya) untuk pembangunan ekonomi nasionalnya (Abubakar, 2009 : 20).

Banks leading the development, besarnya peran perbankan dalam keseluruhan sistem keuangan nasional, menuntut peran lebih dari sektor perbankan yang dapat memberdayakan ekonomi masyarakat guna mengawal pencapaian pertumbuhan ekonomi. Perbankan Indonesia mempunyai fungsi penting dalam aktivitas bisnis dan pembangunan ekonomi, khususnya sebagai lembaga intermediary. Melalui fungsi itu, perbankan menjadi urat nadi perekonomian Indonesia, yang dapat menciptakan kestabilan sistem keuangan, menggerakkan perekonomian dan mendorong pertumbuhan ekonomi nasional sebagaimana tertuang dalam API. Sasaran yang akan dicapai yang ditetapkan oleh API yaitu: 1) Menciptakan struktur perbankan domestik yang sehat yang mampu memenuhi kebutuhan masyarakat dan mendorong pembangunan ekonomi nasional yang berkesinambungan; 2) Menciptakan sistem pengaturan dan pengawasan bank yang efektif dan mengacu pada standar internasional. 3) Menciptakan industri perbankan yang kuat dan memiliki daya saing yang tinggi serta memiliki ketahanan dalam menghadapi risiko. 4) Menciptakan good corporate governance dalam rangka memperkuat kondisi internal perbankan nasional. 5) Mewujudkan infrastruktur yang lengkap untuk mendukung terciptanya industri perbankan yang sehat. 6) Mewujudkan 
pemberdayaan dan perlindungan konsumen jasa perbankan.

Kegiatan usaha perbankan adalah kegiatan yang bergerak atas dasar kepercayaan masyarakat. Setiap pemangku kepentingan (stakeholder) di bidang perbankan wajib menjaga kepercayaan masyarakat tersebut dengan menyelenggarakan pengelolaan atas dasar prinsip kehati-hatian (prudential banking principle) sesuai dengan asas yang dianut oleh perbankan Indonesia berdasarkan Pasal 2 UU perbankan. Mengingat perannya yang begitu strategis, dalam rangka mencapai tujuan pembangunan nasional pemerintah mengadakan pengaturan dan pengawasan yang ketat agar lembaga perbankan di Indonesia berfungsi secara efisien, sehat, wajar serta mampu melindungi secara baik dana yang dititipkan masyarakat serta mampu menyalurkan dana masyarakat tersebut ke bidang-bidang yang produktif guna pencapaian sasaran pembangunan. Dalam hal pengaturan dan pengawasan tersebut Bank Indonesia sebagai pemegang ototitas kebijakan makro bekerjasama dengan Otoritas Jasa Keuangan sebagai pemegang otoritas kebijakan mikro berdasarkan amanat UU No. 21 Tahun 2011 Tentang Otoritas Jasa Keuangan. Pengawasan yang terintegrasi sangat diperlukan dalam kondisi seperti sekarang maupun dimasa yang akan darang oleh karena itu diperlukan kerjasama yang harmonis antara kedua pemegang otoritas perbankan tersebut. Regulasi keuangan sangat penting guna mendukung kegiatan perekonomian agar para pelaku di sektor keuangan dapat bertindak secara adil dan berhati-hati serta tidak menimbulkan risiko sistemik terhadap perekonomian.

Berdasarkan perkembangan kondisi perbankan secara global, maka perbankan Indonesia mendapatkan tantangan baru untuk dapat menyesuaikan dengan kondisi global sehingga bank-bank di Indonesia siap bersaing dengan bank asing. Salah satu upaya untuk mengantisipasi perubahan tersebut maka Otoritas Jasa Keuangan (OJK) dan Bank Indonesia selaku penentu kebijakan mikroprudential dan makroprudential, mendorong industri jasa keuangan untuk meningkatkan kontribusinya dalam pertumbuhan ekonomi nasional dan meningkatkan daya saing.

Menjelang akhir tahun 2015 kinerja perbankan Indonesia dinilai membaik, dan perekonomian Indonesia pun dinilai semakin membaik. Pertumbuhan ekonomi meningkat menjadi 4,73\% pada kuartal ketiga 2015 dari 4,67\% pada kuartal sebelumnya. Selain itu 
pertumbuhan kredit di industri perbankan membaik selama dua bulan berturut-turut (Wisnubroto, 2016). Perbankan Indonesia bertujuan menunjang pelaksanaaan pembangunan nasional dalam rangka meningkatkan pemerataan, pertumbuhan ekonomi, dan stabilitas nasional ke arah peningkatan kesejahteraan rakyat banyak. Sebagaimana diketahui bahwa pembangunan nasional merupakan upaya pembangunan berkesinambungan dalam rangka mewujudkan masyarakat Indonesia yang adil dan makmur berdasarkan Pancasila dan UUD 1945. Sektor perbankan sangat erat kaitannya dengan perekonomian suatu negara, jika sistem perbankan suatu negara sehat maka hal tersebut dapat menunjang pembangunan ekonomi, oleh karena itu terwujudnya suatu sistem perbankan yang sehat perlu dilakukan secara berkesinambungan yang berdampak pada terwujudnya kepastian hukum dalam pelaksanaan kegiatan perbankan di Indonesia melalui prinsip kehatihatian.

Bank merupakan sumber institusi penting dan utama bagi pembiayaan eksternal dalam suatu bisnis hampir disemua negara. Bahkan perannya lebih besar lagi dinegara-negara berkembang tidak terkecuali Indonesia. Peran industri perbankan masih mendominasi sistem keuangan di Indonesia dengan pangsa pasar sekitar 77.9 persen dari total aset lembaga keuangan (Bank Indonesia, 2013). Fungsi bank sebagai intermediary institution memiliki peran strategis kbagi pengembangan perekonomian suatu negara. Karena peran perbankan begitu besar, penting untuk dipastikan bahwa sistem keuangan dan perekonomian suatu negara juga akan berjalan lancar dan efisien. (Aviliani, 2015 : 380)

Dalam menghadapi perkembangan perekonomian nasional yang senantiasa bergerak cepat, kompetitif dan terintegrasi dengan tantangan yang semakin kompleks serta sistem keuangan yang semakin maju, diperlukan penyesuaian kebijakan dibidang ekonomi, termasuk perbankan. Penyesuaian kebijakan dalam bidang perbankan di mulai dengan di laksanakannya pembaruan hukum perbankan melalui revisi UU Perbankan, revisi ini dimaksudkan agar perbankan nasional semakin kokoh mengikuti perkembangan ekonomi dan internasional sehingga kinerja perbankan Indonesia sesuai dengan perkembangan zaman namun tetap memperhatikan kepentingan nasional. Seiring dengan diberlakukannya ABIF pada tahun 2020 seharusnya revisi UU Perbankan ini sudah dapat diundangkan sehingga 
perbankan nasional Indonesia dapat beraktivitas dalam kerangka ABIF dengan legal basis yang kuat.

Perkembangan dunia global khususnya sektor perbankan menyebabkan beberapa substansi yang terdapat dalam UU Perbankan sudah tidak relevan lagi diterapkan di industri perbankan sekarang ini. Pengaturan perbankan perlu dilakukan penyempurnaan baik terkait dengan Undang-undang perbankan itu sendiri. Setelah UU No. 10 Tahun 1998 tentang perbankan itu telah diundangkan banyak perkembangan yang terjadi sebagai contoh, UU No 8 Tahun 2010 Tentang Pencegahan dan Pemberantasan Tindak Pidana Pencucian Uang, UU No. 21 Tahun 2008 Tentang Perbankan Syariah, UU No. 11 Tahun 2008 Tentang Informasi dan Transaksi Elektronik, UU No. 24 Tahun 2004 Tentang Lembaga Penjamin simpanan, UU No 21 Tahun 2011 Tentang Otoritas Jasa Keuangan, Serta yang terakhir adalah UU No 9 Tahun 2016 Tentang Pencegahan dan Penanganan Krisis Sistem Keuangan, adalah undangundang yang ada keterkaitan dengan industri perbankan, oleh karena itu perlu ada nya perubahan UU Perbankan mengingat perkembangan industri perbankan sangat pesat.
Terkait dengan pemenuhan isu global yang masuk dalam prioritas kebijakan yang akan diatur oleh OJK maka dengan adanya MEA pada akhir tahun 2015 lalu, membawa dampak kepada sistem keuangan dan perekonomian di dalam wilayah ASEAN. Negara-negara yang tergabung dalam ASEAN ini diantaranya adalah Brunei Darusalam, Kamboja, Indonesia, Laos, Malaysia, Myanmar, Filipina, Singapura, Thailand, dan Vietnam. Ekonomi ASEAN bergerak maju menuju pembentukan suatu ASEAN Financial Integration, dalam hal ini terkait perbankan maka di bentuklah ASEAN Banking Integration Framework (ABIF). Integrasi Perbankan ASEAN merupakan salah satu sumber dominan pembiayaan untuk pengembangan dan memfasilitasi aliran perdagangan dan investasi.

Meningkatkan keterkaitan dalam sistem keuangan ASEAN diperlukan suatu kerangka peraturan untuk mendukung stabilitas keuangan regional. Menurut penelitian sebelumnya yang mengangkat tema mengenai Cross Border Cooperation Bank In ASEAN (Vivien Chen, 2016 : 2) menjelaskan bahwa: The cooperation is central to the effective implementation of internationally prescribed resolution frameworks for cross border banking 
groups. Such frameworks aim to achieve the smooth resolution of financially distressed financial institution without jeopardising systemic stability or burdening the public purse. Kerjasama tersebut merupakan pusat pelaksanaan resolusi internasional dari kerangka lintas perbankan yang efektif. Kerangka tersebut bertujuan untuk mencapai resolusi yang lancar dari lembagalembaga keuangan yang mengalami kesulitan keuangan tanpa membahayakan stabilitas sitemik atau dompet (kas keuangan) publik.

Tujuan dibentuk ABIF yaitu dimulai dengan semangat untuk mendorong proses integrasi perbankan ASEAN dengan tetap menjaga stabilitas keuangan regional. ABIF telah menetapkan ketentuan-ketentuan dasar bagi negara-negara ASEAN untuk dapat masuk ke dalam pengaturan bilateral yang bertujuan membentuk Bank ASEAN yang Berkualitas (Qualified ASEAN Banks (QABs)) dengan akses pasar yang lebih besar dan fleksibilitas operasional. Maksud dari fleksibilitas operasional disini adalah QABs akan diberikan perlakuan yang sama dengan perlakuan yang diberikan ke bank pribumi di Host Country. Fleksibilitas operasional mengacu pada bidangbidang seperti: ruang lingkup kegiatan, penyediaan produk dan jasa, dan fleksibilitas lainnya yang mungkin disepakati antara tuan rumah dan negara asal (Yati Kurniati, 2016). Oleh karena itu, perlu langkah untuk dapat mempersiapkan perbankan Indonesia agar memenuhi kategori Bank berkualitas ASEAN.

Pemerintah Indonesia menyambut kehadiran ABIF dan siap dalam implementasinya dengan tetap menjaga kepentingan nasional, hal ini menjadi tanggung jawab OJK untuk mengimplementasikan kerangka ABIF. Kebutuhan perbankan nasional untuk ekspansi di wilayah ASEAN akan dikawal oleh OJK melalui kerangka ABIF. Hal ini dilakukan melalui negosisasi dalam rangka pembuatan perjanjian bilateral, Indonesia akan dapat mengirimkan bank-bank terpilih sebagai Qualified ASEAN Bank (QAB). Kerjasama bilateral ini didasarkan pada prinsip resiprokalitas dan reducing the gaps. Prinsip Resiprokalitas adalah prinsip yang mengutamakan adanya kesetaraan nilai manfaat yang diterima oleh keduabelah pihak, sedangkan prinsip reducing the gaps adalah prinsip yang mengutamakan upaya mengecilkan kesenjangan yang ada. Kedua prinsip tersebut diacu dalam pembuatan Heads of Agreement antara keduabelah pihak dan akan terus dijadikan acuan ketika OJK melakukan negosiasi dan membuat 
perjanjian dengan negara anggota ASEAN lainnya ( OJK, 2014).

Bank Indonesia telah menyepakati kriteria umum bank yang masuk ke dalam kategori Qualified ASEAN Bank atau bank-bank yang memiliki kualifikasi untuk berekspansi di kawasan ASEAN. Kriteria yang dimaksud adalah (Alamsyah, $2016: 1$ ) Dikelola dengan baik (Well Managed); 2) Memiliki cukup banyak modal (Well Capitalised) 3)Bank mendapatkan Rekomendasi dari otoritas (Recomended by authorities) 4) Lulus Ketentuan Basel; dan 5) Merupakan Bank yang dinilai penting dinegara asalnya.

OJK memberikan focus perhatiannya terhadap pengembangan industri perbankan dalam jangka menengah yang diharapkan mampu merespon perubahan lingkungan internal dan eksternal industri perbankan. Adapun yang menjadi target dari pengembangan industri perbankan tersebut adalah: (OJK, $2016:$ 1) Melanjutkan pertumbuhan perbankan yang pesat tercermin dari aset, pembiayaan, penghimpun dana masyarakat dengan memperhatikan shifting portofolio perbankan yang diarahkan untuk pemenuhan pendanaan sektor-sektor ekonomi prioritas dan memberikan multiplier effect yang tinggi. Sehubungan dengan hal tersebut, bank perlu melakukan perubahan struktur pendanaan yang masih didominasi dana-dana jangka pendek dan mahal. Hal ini berpengaruh pada potofolio pembiayaan bank yang juga cenderung membiayai sektor-sektor berjangka pendek dengan return yang tinggi seperti perdagangan dan jasa serta kredit konsumtif dan peningkatan portofolio pembiayaan UMKM yang juga didominasi pada sektor yang sama. 2) Meningkatkan kemampuan perbankan dalam menjangkau masyarakat yang selama ini belum atau kurang mendapat akses keuangan melalui inisiatif keuangan inklusif dan laku pandai (branchless banking). 3) Memperkuat manajemen risiko bank serta pelaksanaan Good Corporate Governance (GCG) untuk mendukung proses Shifting Portofolio dan perluasan layanan serta memperkuat daya tahan perbankan menghadapi kondisi krisis. Hal ini penting agar pembenahan manajemen risiko termasuk kecukupan permodalan harus didukung pengawasan berbasis risiko yang telah terbukti meningkatkan daya tahan industri perbankan dalam menghadapi krisis baik yang datangnya dari domestik maupun imbas dari krisis keuangan global. Penguatan daya tahan ini tercermin dari penerapan Basel III secara bertahap sebagai kelanjutan Basel II. Sementara 
untuk perbankan syariah dan BPR dilakukan upaya percepatan implementasi manajemen risiko pada operasional bank dan pengawasan berbasis risiko. 4) Meningkatkan peranan perbankan dalam pendanaan sektor-sektor usaha yang ramah lingkungan sebagai bagian dari implementasi roadmap keuangan berkelanjutan (RKB). 5) Mempercepat penataan struktur industri perbankan nasional yang diarahkan pembentukan bank nasional yang kuat dan sehat sehingga tidak hanya mampu melayani kebutuhan domestik namun mampu bersaing di tingkat ASEAN.

\section{Simpulan}

Berdasarkan hasil analisis dan pembahasan, dapat disimpulkan sebagai berikut : Pembaruan hukum perbankan Indonesia memegang peran penting untuk menjaga stabilitas sistem keuangan nasional, yang dipengaruhi oleh kondisi keuangan dan perbankan global, guna mempersiapkan ketahanan perbankan nasional terhadap krisis dan persaingan, khususnya menghadapi kesepakatan ABIF yang akan berlaku pada tahun 2020. Diperlukan adanya pembaruan hukum perbankan sebagai bidang hukum yang bersifat netral agar dapat mengakomodasikan perkembangan regulasi dan standar perbankan yang dikeluarkan oleh lembaga-lembaga internasional, dimana Indonesia menjadi anggotanya. Sementara itu, upaya pemerintah yang dapat dilakukan agar perbankan Indonesia siap menghadapi kesepakatan ABIF adalah dengan membuat landasan hukum yang kokoh antara lain ; untuk meningkatkan kemampuan perbankan dalam menjangkau masyarakat yang selama ini belum atau kurang mendapat akses keuangan melalui inisiatif keuangan inklusif dan laku pandai (branchless banking); memperkuat manajemen risiko bank serta pelaksanaan Good Corporate Governance; memperkuat daya tahan perbankan menghadapi kondisi krisis; meningkatkan peranan perbankan dalam pendanaan sektor-sektor usaha yang ramah lingkungan sebagai bagian dari implementasi roadmap keuangan berkelanjutan $(R K B)$; serta mempercepat penataan struktur industri perbankan nasional.

\section{Daftar Pustaka}

\section{Buku}

Abubakar, Lastuti, 2009, Transaksi Derivatif Di Indonesia; Tinjauan Hukum Tentang Perdagangan Derivatif di Bursa Efek, Bandung : Books Terrace \& Library.

Hartono, Sunaryati, 1988, Hukum Ekonomi Pembangunan Indonesia, Bandung : Binacipta. 
Ibrahim, Jhonny, 2013, Teori \& Metodologi Penelitian Hukum Normatif, Malang : Bayumedia.

Kusumaatmadja, Mochtar, 2002, Konsep-konsep hukum dalam Pembangunan; Kumpulan Karya Tulis, Bandung : Alumni.

Mamudji, Sri. 2005, Metode Penelitian Dan Penulisan Hukum, Jakarta : Badan Penerbit Fakultas Hukum Universitas Indonesia

Sumadi, 1988, Metode Penelitian, Jakarta : CV Rajawali.

\section{Jurnal}

Aviliani, The Impact of Macroeconomic Condition On The Bank's Performance in Indonesia, Buletin Ekonomi Moneter dan PErbankan, Vol 17 Nomor 4 April 2015.

\section{Makalah}

Kurniati, Yati, Macroprudential Makalah: Departement, Central Bank), Advances and Challenges In Regional Integration, Disampaikan pada pertemuan Di Tokyo-Jepang yang di selenggarakan oleh Hitosubashi
University And IMF Regional Offices For Asia an The Pasific, 34 Maret 2016.

\section{Website}

Alamsyah, Halim. 2014, Ada lima Kriteria Qualified ASEAN Bank, Apa Saja?, (diakses pada tanggal 27 Oktober 2016) http://finansial.bisnis.com/read/20 140718/90/244401/ada-5-kriteriaqualified-asean-bank-apa-saja.

Chen, Vivien. 2016, Cross Border Cooperation in Bank Resolution: A Framework For ASIA, Singapore Journal Of Legal Studies, diakses pada tanggal 2 Oktober 2016 , http://law.nus.edu.sg/sjls/articles/S JLS-Mar-16-1.pdf .

OJK, Booklet Perbankan Tahun 2016 , Diakses pada tanggal 29 September 2016, www.ojk.co.id.

Wisnubroto, Rully A, Analysis; Challenges For Indonesia Banking Industry in 2016, Diakses pada tanggal 29 September 2016 , http://www.thejakartapost.com/ne ws/2015/12/16/analysischallenges-indonesian-bankingindustry-2016.html. 